\title{
Effect of Dietary Calorie and Protein Content on Performance, Behaviour, Expression of some Growth-Related Genes and Economic of Broiler Chickens Rania El Sayed ${ }^{1}$, Doaa Ibrahim ${ }^{1 *}$ and Enas N. Said ${ }^{2}$ \\ ${ }^{1}$ Nutrition and Clinical Nutrition Department, Faculty of Veterinary Medicine, Zagazig University, 44511, Egypt \\ ${ }^{2}$ Veterinary Public Health Department, Faculty of Veterinary Medicine, Zagazig University, 44511, Egypt
}

Article History: Received: 24/7/2017 Received in revised form: 30/10/2017 Accepted: 5/11/2017

\begin{abstract}
The goal of this study was to evaluate the effects of variable dietary metabolizable energy and crude protein concentrations on the performance, behaviour, expression of growth related genes and economic impact of broiler chickens. A total of 250 Cobb broiler chicks were divided randomly into five groups of ten replicates (10 chicks/replicate). Five diets with five different combinations of calories and protein were formulated as the following; normal energy and normal protein (NENP), low energy and high protein (LEHP), high energy and low protein (HELP), normal energy and low protein (NELP), low energy and normal protein (LENP) during starter and finisher period. The results revealed that the highest body weight and body weight gain were observed in the HELP and NELP groups which were similar in improvement of feed utilization and protein efficiency ratio. The total feed intake was increased with decreased dietary energy as in NENP group. Nutrient digestibility was improved with increasing diet energy density as in HELP and NELP groups. The expression of IGF-1 and growth hormone genes were markedly higher in HELP and NELP groups, while the myogenin expression significantly increased in HELP, NELP and LEHP groups. Moreover, the final weight greatly correlated with the gene expression related to growth. Eating and drinking frequencies were highest in LENP and LEHP groups. Birds reared in HELP diet were more active, as expressed by greater walking, wing shaking, leg stretch, preening and flying. Briefly, our results suggested that the energy of diets greatly affected the broiler performance, behaviour and digestibility. Additionally, inclusion of low protein diet with addition of critical amino acids had a positive effect on economic efficiency of broilers. Thus, NELP and HELP diets are recommending for growth of Cobb broiler and could have a significant economic impact.
\end{abstract}

Keywords: Low protein diet, Performance, Digestibility, Gene expression, Broiler chicken.

\section{Introduction}

In a commercial poultry production, nutrient density is the most critical nutritional aspect, because it has a significant impact on performance and health of poultry, which in turn influence the cost-effectiveness [1,2]. Dietary crude protein $(\mathrm{CP})$ requirements are high in modern broiler strains due to the fast growth rates which consequently increasing the overall cost of finished product [3]. The carcass characteristics can be altered through manipulation of dietary protein and/or energy in broilers [4].

Synergy between protein and energy specified the importance of a well-adjusted calorie: protein $(\mathrm{C}: \mathrm{P})$ ratio to attain optimum performance and carcass characters of broilers. The energy requirements have a great role in broiler production. High energy during the starter period resulted in high fat accumulation [5], consequently dietary energy wastage [6]. Saleh et al. [7] revealed that using fat to widen the calorie:protein ratio will increase energy intake, which increasing fat deposition. There are two important aspects controlling production; firstly, increasing the energy:protein ratio thus ensuring that all the protein will be utilized for fast growth, secondly, decrease energy amount to produce leaner carcasses. On the other hand, protein quality of different feed ingredients directly depends upon the availability of critical amino acids. Therefore, a correct level of protein with high biological value in the ration is importance for optimum economic performance [8]. Broilers fed on a CP level 
and supplemented with methionine and lysine performed well [9]. Deficiency of either individual or mixture of limiting amino acids lysine, methionine, threonine, valine, isoleucine and tryptophan may lead to broiler growth retardation [10,11]. Among the amino acids, methionine is the primarily essential for initiating protein synthesis and affect myogenin expression of broilers muscle [12]. Furthermore, lysine, methionine, valine, and threonine isoleucine are essential components of muscle protein and their deficiency can reduce the body weight gain.

Insulin-like growth factor-1 (IGF-1) positively associated with growth rate in meattype poultry. The chicken IGF-1 hormone is important for cell proliferation and enhancing the rate of metabolism [13]. Nutrition quality and quantity can modify growth hormone (GH) and hepatic IGF-1 expression [14]. High dietary protein supplementation with arginine, methionine and cysteine improved the level of plasma IGF-I and weight gain in chicks [15]. Armstrong and Britt [16] showed that the changes in dietary energy and protein content associated with growth hormone concentration in serum. Thus, optimal broiler production requires an appropriate combination of dietary energy and protein with optimum content and availability of critical amino acids. Therefore, the present study was planned to investigate the impact of altering dietary energy and protein with supplemental amino acids on broiler performance, digestibility, behaviour and economic. Moreover, evaluating the appropriate dietary protein and energy level through the expression of IGF-1, growth hormone, myogenin and myostatin levels of Cobb broiler chicken.

\section{Materials and Methods}

\section{Birds, management, and experimental design}

All the experimental procedures were carried out in accordance with the regulations of local experimental animal care committee and approved by the institutional ethics committee.

A total number of 250 day old chicks of a commercial meat type (Cobb) obtained from a local hatchery were used in this study. On arrival, they were weighed and randomly allocated to equal five treatment groups. Each containing five replicates (10 birds/replicate). Birds were reared in a naturally ventilated open house with saw dust as litter, and at a density of $10 \mathrm{birds} / \mathrm{m}^{2}$. Continuous lighting was provided throughout the experiment. The temperature was $33^{\circ} \mathrm{C}$ at the beginning and then decreased gradually $2{ }^{\circ} \mathrm{C}$ each week until reached $21^{\circ} \mathrm{C}$ at the $6^{\text {th }}$ week. Birds vaccinated with Hitchner B1 ( $1^{\text {st }}$ day/eye drop), CoccivacB ( $2^{\text {nd }}$ day/eye drops), Avian influenza (7 days/S/C injection), Gumboro (11 days/eye drop), LaSota (17 days/drinking water) and Gumboro (22 days /drinking water). 
Table 1: Ingredients and nutrient composition of the basal diet of cobb broiler chickens

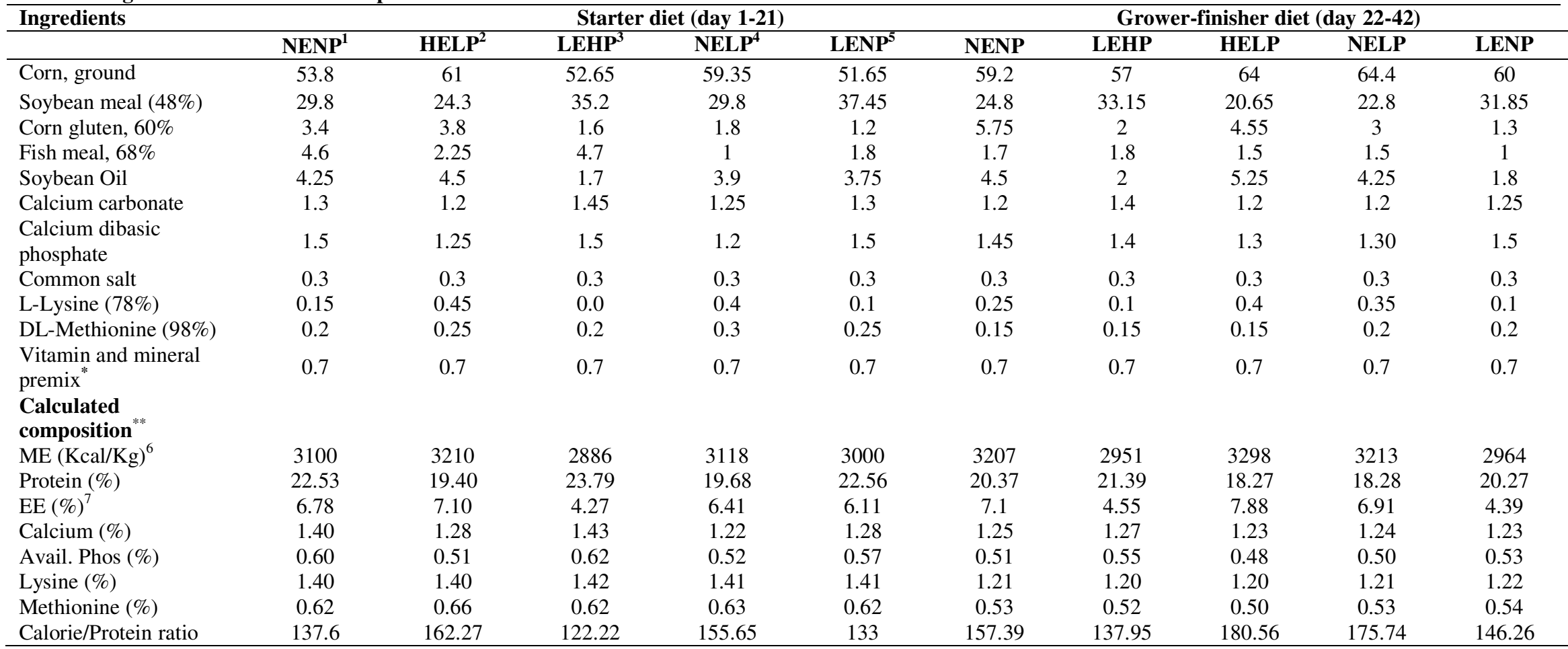

Muvco premix: Each3 kg contains vit.A (10.000000 IU). vit. D3 (2,000000 IU), vit.E (10g), vit k3 (1000 mg), vit.B1 (100mg), vit.B2(5g), vit.B6(1.5g), pantothenic acid $(10 \mathrm{~g})$, vit.B12(10 mg), niacin (30 g), folic acid (1000 mg), biotin (50g), fe (30 g), Mn (60 g), Cu (4g), I (300 mg ), Co (100mg), Se (100 mg) and Zn (50 g ).

${ }^{1} \mathrm{NENP}=$ normal energy normal protein diet, ${ }^{2} \mathrm{HELP}=$ high energy and low protein diet, ${ }^{3} \mathrm{LEHP}=$ low energy and high protein diet, ${ }^{4} \mathrm{NELP}=$ normal energy and low protein diet, ${ }^{5} \mathrm{LENP}=$ low energy and normal protein diet. ${ }^{6} \mathrm{ME}=$ Metabolizable energy. ${ }^{7} \mathrm{EE}=$ Ether extract 


\section{Experimental diets and design}

The experimental diet was formulated to meet the nutrient requirements set by NRC [17] (Table 1). The experiment was extended for 6 weeks and the feeding period was divided to starter and grower-finisher period (Table 2). The proximate analysis of the used feed ingredients was carried out according to the standard procedures of AOAC [18]. All chemical analyses of diets were done in triplicates. Five types of broiler chicken starter and grower-finisher diets were formulated as the following: normal energy and normal protein (NENP), low energy and high protein (LEHP), high energy and low protein (HELP), normal energy and low protein (NELP) and low energy and normal protein (LENP). Levels of essential amino acid were maintained in all the diets by supplementing low CP diets with free amino acids (lysine and methionine).

\section{Growth performance indices and carcass characteristics}

Broiler performance was assessed in terms of body weight, body weight gain (BWG) feed intake (FI), feed conversion ratio (FCR) at the end of starter and grower-finisher period. At the end of rearing period the allover performance was recorded including protein efficiency ratio (PER). Five chicks from each experimental unit were selected randomly and slaughtered to estimate the dressing percentage, abdominal fat weight and meat analysis [18].

\section{Digestibility trails}

At the end of the growth trial five chickens from each group were randomly selected to carry out the digestibility trail (five trials). Each group was supplied by its original feed with addition of chromic oxide $(0.3 \%$, analytical marker) [19] for 7 days (as a preliminary period) and then the excreta were collected daily on a plastic sheet for another 7 days (as a collecting period).

\section{Determination of uric acid and chromium oxide $\left(\mathrm{Cr}_{2} \mathrm{O}_{3}\right)$}

Uric acid concentration in excreta was carried out according to Maquardt [20], while the concentration of $\mathrm{Cr} 2 \mathrm{O} 3$ in both feed and excreta was determined by spectrophotometer.

The digestibility of dry matter of each diet was calculated by the following equation:

Digestibility $\%=$

$\%$ indicator in faeces - \% indicator in feed

$\%$ indicator in faeces

X100

The digestibility of nutrients of each diet was calculated from the following equation: -

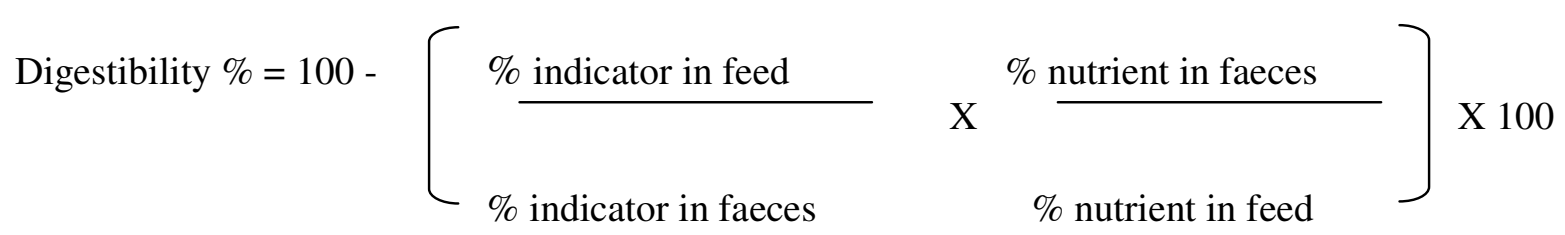




\section{Behavioural observations}

Direct observations of chicken's behaviors were done using scanning technique [21]. Each group was observed $3 \mathrm{~h} /$ week for 6 consecutive weeks for recording the different behavioral patterns (eating, drinking, idling, walking, lying, sleeping, preening, wing shaking, leg stretches and flying).

\section{Real-time quantitative RT-PCR}

At the end of experiments and immediately after slaughter liver and breast muscle were dissected and frozen in trizole to assay the growth hormone, insulin- like growth factor-1, myogenin and myostatin genes. Samples were stored at $-20^{\circ} \mathrm{C}$ in a plastic tube for RNA isolation. Total RNA was extracted from tissue samples using Qiagen RNA extraction kits, (Cat, No. 74104). Total RNA purity was measured using NanoDrop_ND-1000 Spectrophotometer (Nano-Drop Technologies, Wilmington, DE, USA). The total RNA was reverse transcribed into cDNA by using QIAGEN Long Range 2 Step RT-PCR Kit, following the manufacturer's instructions. One $\mu \mathrm{L}$ of total cDNA was mixed with $12.5 \mu \mathrm{L}$ of 2x SYBR Green PCR mix with ROX from Bio-Rad, $5.5 \mu \mathrm{l}$ of D.D water and $0.5 \mu \mathrm{L}$ of each forward and reverse primers for the measured genes. The $\beta$-actin gene was used as a control for normalization. The up-and downstream primer sequences of growth hormone, insulin- like growth factor-1, myogenin and myostatin genes are: $\mathrm{GH}$ primers F: GCC CTG GCA GCC CTG TTA ACC, R: CAC CCC ACC ATC GTA TCC CATC; IGF-1 primers (F: CAG AGC AGA TAG AGC CTG CG and R: TCT GCA GAT GGC ACA TTC AT), Myostatin primers (F: ATG CAA AAG CTA GCA GTC TATG and R: ACT CCG TAG GCA TTG TGA TAAT), Myogenin primers ( $\mathrm{F}$ : AGC AGC CTC AAC CAG CAG GA and R: TCT GCC TGG TCA TCG CTC AG) and $\beta$-actin primers (F: AAT GAG AGG TTC AGG TGC CC and R: ATC ACA GGG GTG TGG GTG TT).

\section{Economic efficiency calculation}

Economic efficiency was calculated according to the following equation: $\mathrm{Y}=[(\mathrm{A}-$
$\mathrm{B}) / \mathrm{B} X$ 100] [22] where, $\mathrm{A}$ is the selling cost and $\mathrm{B}$ is the feeding cost.

\section{Statistical analyses}

Data were analyzed by using the General Linear Model procedure (SPSS). Difference among means was compared using Duncan's multiple range test. Data were presented as mean $\pm \mathrm{SE}$ and significance was declared at $(\mathrm{P}$ $<0.05)$.

\section{Results \\ Broilers performance and carcass characteristics}

The highest body weight (BW) in the starter period was detected in groups fed on LEHP, HELP and NELP, while the feed intake didn't affect by dietary treatment. The final body weight and body weight gain were significantly increased $(\mathrm{p}<0.05)$ in the group fed HELP, NELP, LENP and LEHP, respectively, while, the lowest values were recorded in NENP fed group. The all-over feed intake (TFI) was increased in groups fed on dietary low energy content and the similar for the group fed low protein content when compared with other groups. The allover feed conversion ratio and PER were significantly improved in the group fed HELP and NELP, respectively (Table 1). In spite of the dry matter digestibility values were similar among the groups, but the highest value was reported in the group fed HELP, NELP and LENP, while it tended to be lower for those fed NENP and LEHP (Table 2). The crude protein (CP) digestibility tended to be increased in the group fed HELP and NELP, while the lowest was recorded in LEHP and LENP groups. The values of starch digestibility significantly increased $(\mathrm{p}<0.05)$ in groups fed NENP, HELP and NELP than other groups. Fat digestibility tended to be increased in groups fed NENP, NELP and HELP, while the lowest values were recorded in groups fed LEHP and LENP. Dressing \%, abdominal fat and meat chemical composition didn't reveal any significant difference among different dietary treatment (Table 3). 
Table 2: Performance characteristics of broilers chicken fed on varying dietary calorie and protein content (starter, grower- finisher and allover periods), nutrients digestibility and carcass characteristics of broilers (at 6 weeks of age)

\begin{tabular}{|c|c|c|c|c|c|}
\hline Parameters & NENP $^{1}$ & HELP $^{2}$ & LEHP $^{3}$ & NELP $^{4}$ & LENP $^{5}$ \\
\hline \multicolumn{6}{|c|}{ Starter period (day 1 to 21 ) } \\
\hline $\mathrm{BW}(\mathrm{g} / \mathrm{bird})^{6}$ & $746 \pm 3.85^{\mathrm{b}}$ & $821 \pm 2.4^{\mathrm{a}}$ & $837 \pm 1.66^{\mathrm{a}}$ & $813 \pm 1.28^{\mathrm{a}}$ & $742 \pm 3.83^{\mathrm{b}}$ \\
\hline BWG $(\mathrm{g} / \mathrm{bird})^{7}$ & $700 \pm 4.02^{\mathrm{b}}$ & $775 \pm 2.63^{\mathrm{a}}$ & $791 \pm 2.74^{\mathrm{a}}$ & $766 \pm 1.4^{\mathrm{a}}$ & $695 \pm 4.00^{\mathrm{b}}$ \\
\hline $\mathrm{FI}(\mathrm{g} / \mathrm{bird})^{8}$ & $1335.6 \pm 36.83$ & $1367.4 \pm 35.64$ & $1297 \pm 30.73$ & $1323 \pm 30.86$ & $1290 \pm 32.62$ \\
\hline $\mathrm{FCR}^{9}$ & $1.90 \pm 0.06^{\mathrm{a}}$ & $1.77 \pm 0.05^{\mathrm{abc}}$ & $1.64^{\mathrm{c}} \pm 0.07^{\mathrm{c}}$ & $1.73 \pm 0.04^{\mathrm{bc}}$ & $1.85 \pm 0.08^{\mathrm{ab}}$ \\
\hline \multicolumn{6}{|c|}{ Grower-finisher period (day 22 to 42 ) } \\
\hline BW (g/bird) & $2111 \pm 1.40^{\mathrm{d}}$ & $2432 \pm 3.14^{\mathrm{a}}$ & $2292^{\mathrm{c}} \pm 2.92^{\mathrm{c}}$ & $2371 \pm 2.08^{\mathrm{b}}$ & $2284 \pm 1.83^{\mathrm{c}}$ \\
\hline BWG (g/bird) & $1365 \pm 13.56^{\mathrm{d}}$ & $1611 \pm 2.86^{\mathrm{a}}$ & $1454^{\mathrm{c}} \pm 1.98^{\mathrm{c}}$ & $1558 \pm 0.87^{\mathrm{b}}$ & $1542 \pm 5.18^{\mathrm{b}}$ \\
\hline FI (g/bird) & $2911 \pm 21.97^{\mathrm{b}}$ & $2875 \pm 21.09^{\mathrm{b}}$ & $3073^{\mathrm{a}} \pm 22.68^{\mathrm{a}}$ & $3105 \pm 18.76^{\mathrm{a}}$ & $3151 \pm 23.57^{\mathrm{a}}$ \\
\hline FCR & $2.14 \pm 0.02^{\mathrm{a}}$ & $1.79 \pm 0.02^{\mathrm{c}}$ & $2.116 \pm 0.01^{\mathrm{a}}$ & $1.99 \pm 0.012^{\mathrm{b}}$ & $2.04 \pm 0.02^{\mathrm{b}}$ \\
\hline \multicolumn{6}{|l|}{ Allover period } \\
\hline FBW $(\mathrm{g} / \mathrm{bird})^{10}$ & $2111 \pm 2.40^{\mathrm{d}}$ & $2432 \pm 2.14^{\mathrm{a}}$ & $2292 \pm 1.92^{\mathrm{c}}$ & $2371 \pm 1.55$ & $2284 \pm 2.83^{\mathrm{c}}$ \\
\hline BWG (g/bird) & $2065 \pm 1.51^{\mathrm{d}}$ & $2386 \pm 2.70^{\mathrm{a}}$ & $2246 \pm 2.6^{\mathrm{c}}$ & $2325 \pm 2.19^{\mathrm{b}}$ & $2237 \pm 2.90^{\mathrm{c}}$ \\
\hline TFI (g/bird $)^{11}$ & $4247 \pm 25.43^{\mathrm{c}}$ & $4243 \pm 20.72^{\mathrm{c}}$ & $4370 \pm 20.55^{\mathrm{b}}$ & $4428 \pm 15.50^{\mathrm{a}}$ & $4441 \pm 25.73^{\mathrm{a}}$ \\
\hline FCR & $2.05 \pm 0.04^{\mathrm{a}}$ & $1.78 \pm 0.02^{\mathrm{d}}$ & $1.95 \pm 0.06^{\mathrm{abc}}$ & $1.90 \pm 0.01^{\mathrm{c}}$ & $1.98 \pm 0.01^{\mathrm{ab}}$ \\
\hline $\mathrm{PER}^{12}$ & $2.32 \pm 0.04^{\mathrm{d}}$ & $2.68 \pm 0.02^{\mathrm{a}}$ & $2.46 \pm 0.01^{\mathrm{bc}}$ & $2.51 \pm 0.01^{\mathrm{b}}$ & $2.411 \pm 0.01^{\mathrm{c}}$ \\
\hline \multicolumn{6}{|c|}{ Nutrients digestibility (\%) } \\
\hline Dry matter & $70.66 \pm 0.90^{\mathrm{b}}$ & $71.48 \pm 0.86^{\mathrm{a}}$ & $69.84^{\mathrm{b}} \pm 0.60^{\mathrm{b}}$ & $71.56 \pm 0.53^{\mathrm{a}}$ & $71.16 \pm 0.51^{\mathrm{a}}$ \\
\hline Crude protein & $63.50 \pm 0.40^{\mathrm{b}}$ & $64.46 \pm 0.44^{\mathrm{a}}$ & $62.68^{\mathrm{b}} \pm 0.47^{\mathrm{b}}$ & $64.42 \pm 0.26^{\mathrm{a}}$ & $62.56 \pm 0.43^{\mathrm{ab}}$ \\
\hline Starch & $85.92 \pm 0.27^{\mathrm{a}}$ & $86.84 \pm 0.55^{\mathrm{a}}$ & $85.60^{\mathrm{b}} \pm 0.13^{\mathrm{b}}$ & $86.76 \pm 0.41^{\mathrm{a}}$ & $85.60 \pm 0.27^{\mathrm{b}}$ \\
\hline Fat & $85.72 \pm 0.53^{\mathrm{a}}$ & $86.50 \pm 0.18^{\mathrm{ab}}$ & $85.28 \pm 0.38^{\mathrm{b}}$ & $86.58 \pm 0.52^{\mathrm{a}}$ & $85.30 \pm 0.24^{\mathrm{b}}$ \\
\hline \multicolumn{6}{|c|}{ Carcass characteristics } \\
\hline Dressing $(\%)$ & $72.36 \pm 1$ & $73.5 \pm 1.2$ & $72.6 \pm 1.2$ & $73.61 \pm 0.9$ & $73.1 \pm 0.8$ \\
\hline Abdominal fat (g) & $2.20 \pm 0.09$ & $2.3 \pm 0.05$ & $1.99 \pm 1$ & $2.10 \pm 0.06$ & $2.3 \pm 0.07$ \\
\hline \multicolumn{6}{|l|}{ Meat analysis (\%) } \\
\hline Moisture & $75.32 \pm 0.70$ & $76.56 \pm 0.12$ & $75.90 \pm 0.30$ & $76.72 \pm 0.69$ & $75.80 \pm 0.9$ \\
\hline Protein & $22.90 \pm 0.7$ & $23.38 \pm 1.2$ & $22.62 \pm 1.1$ & $22.9 \pm 0.9$ & $22.46 \pm 0.9$ \\
\hline
\end{tabular}


Table 3: Behaviors of cobb broiler chickens under varying dietary calorie and protein

\begin{tabular}{|c|c|c|c|c|c|}
\hline & NENP $^{1}$ & HELP $^{2}$ & LEHP $^{3}$ & NELP $^{4}$ & LENP $^{5}$ \\
\hline Eating & $23.6 \pm 0.67^{\mathrm{c}}$ & $20.00 \pm 1.15^{\mathrm{d}}$ & $44.05 \pm 0.91^{b}$ & $41.50 \pm 0.34^{b}$ & $46.6 \pm 0.87^{\mathrm{ab}}$ \\
\hline Drinking & $13.60 \pm 0.70^{\mathrm{c}}$ & $10.93 \pm 0.06^{\mathrm{d}}$ & $16.60 \pm 1.22^{\mathrm{b}}$ & $18.53 \pm 0.77^{\mathrm{ab}}$ & $20.53 \pm 0.51^{\mathrm{a}}$ \\
\hline Idling & $47.10 \pm .23^{\mathrm{b}}$ & $42.56 \pm 0.45^{\mathrm{b}}$ & $48.90 \pm 0.68^{b}$ & $26.00 \pm 0.20^{c}$ & $66.16 \pm 0.51^{\mathrm{a}}$ \\
\hline Walking & $25.53 \pm 1.30^{\mathrm{bc}}$ & $41.50 \pm 0.53^{\mathrm{a}}$ & $21.46 \pm 0.9^{\mathrm{b}}$ & $31.90 \pm 0.47^{\mathrm{b}}$ & $21.00^{c} \pm 0.46^{c}$ \\
\hline Lying & $62.53 \pm 0.45$ & $60.70 \pm 0.14$ & $70.13 \pm 0.71$ & $61.03 \pm 0.25$ & $65.23 \pm 0.92$ \\
\hline Sleep & $61.33 \pm 0.97^{\mathrm{bc}}$ & $62.13 \pm 1.09^{\mathrm{bc}}$ & $65.56 \pm 0.62^{\mathrm{ab}}$ & $58.63 \pm 1.08^{c}$ & $68.46 \pm 1.12^{\mathrm{a}}$ \\
\hline Preening & $9.26 \pm 0.43^{\mathrm{b}}$ & $11.6 \pm 0.08^{\mathrm{a}}$ & $6.56 \pm 0.54^{c}$ & $9.30 \pm 0.60^{\mathrm{b}}$ & $6.70 \pm 0.60^{c}$ \\
\hline Wing shaking & $8.46 \pm 0.58^{\mathrm{abc}}$ & $10.86 \pm 0.68^{a}$ & $7.00 \pm 1.32^{\mathrm{bc}}$ & $8.96 \pm 0.37^{\mathrm{ab}}$ & $6.33 \pm 0.16^{\mathrm{c}}$ \\
\hline Leg stretching & $5.97 \pm 0.94^{\mathrm{b}}$ & $8.46 \pm 0.52^{\mathrm{a}}$ & $4.10 \pm 0.49^{b}$ & $9.06 \pm 1.23^{\mathrm{a}}$ & $4.53 \pm 0.29^{b}$ \\
\hline Flying & $6.03 \pm 0.23^{\mathrm{ab}}$ & $6.36 \pm 0.18^{\mathrm{a}}$ & $5.43 \pm 0.23^{\mathrm{b}}$ & $6.20 \pm 0.15^{\mathrm{ab}}$ & $4.23 \pm 040^{\mathrm{c}}$ \\
\hline
\end{tabular}

${ }^{1} \mathrm{NENP}=$ normal energy normal protein diet, ${ }^{2} \mathrm{HELP}=$ high energy and low protein diet, ${ }^{3} \mathrm{LEHP}=$ low energy and high protein diet, ${ }^{4} \mathrm{NELP}=$ normal energy and low protein diet, ${ }^{5} \mathrm{LENP}=$ low energy and normal protein diet. 


\section{Behaviour observations}

Eating behaviour was differed among the experimental groups. The, highest frequency was recorded in LENP group, while the lowest was in HELP group. Birds fed on HELP were more active that expressed by a significant increase in walking, flying, preening, wing shaking and leg stretching activities. In contrast, the lowest results for these activities were observed in LENP group with an increase in frequencies of idling and sleeping. There were no significant differences in lying frequencies among different dietary groups.

\section{Gene expression}

The highest mRNA expression levels of IGF-I and GH $(P<0.05)$ were in HELP and NELP groups when compared with other groups. Normal or high dietary energy level with low protein significantly increased $(P<0.05)$ the expression of IGF-I than normal or high dietary protein with low energy or normal protein with normal energy level. The myognin mRNA expression in muscle was increased $(P<0.05)$ in HELP than LELP. Additionally, expression of myognin was also higher in LEHP group, although its weight didn't correspond to the increase in muscle myognin expression. Inversely, HELP group decreased mRNA expression for the muscle myostatin gene (Fig. 1).

\section{Economic efficiency}

The most economically efficient ratio from dietary energy and protein was observed in HELP (232.53\%) and NELP (224.43\%) groups (Table 4).

Table 4: Effect of varying dietary calorie and protein content on economic efficiency of cobb broiler chickens

\begin{tabular}{lccccc}
\hline Parameters & NENP $^{1}$ & HELP $^{2}$ & LEHP $^{\mathbf{3}}$ & NELP $^{4}$ & LENP $^{\mathbf{5}}$ \\
\hline Diet cost (L.E*/kg diet) & 4.15 & 3.61 & 4.13 & 3.56 & 3.95 \\
Feeding cost of obtained gain (L.E) & 17.62 & 15.79 & 17.51 & 15.76 & 17.55 \\
Bird selling cost of obtained gain (L.E/kg live & 22 & 22 & 22 & 22 & 22 \\
weight) & & & & 51.13 & 49.21 \\
Selling cost of obtained gain (L.E) & 45.43 & 52.49 & 49.39 & 53.43 & 180.48 \\
Economic efficiency (\%) & 93.81 & 232.53 & 182.10 & 224.43 \\
\hline
\end{tabular}

L.E* Egyptian Pound.

${ }^{1} \mathrm{NENP}=$ normal energy normal protein diet, ${ }^{2} \mathrm{HELP}=$ high energy and low protein diet, ${ }^{3} \mathrm{LEHP}=$ low energy and high protein diet, ${ }^{4} \mathrm{NELP}=$ normal energy and low protein diet, ${ }^{5} \mathrm{LENP}=$ low energy and normal protein diet.

\section{Discussion}

\section{Growth performance and carcass} characteristics

The effect of dietary energy on the performance of growing birds depends on the capacity of the bird to alter feed intake for meeting their demands with respect to their calories [23]. The dietary calorie: protein ratio plays an important role in broiler performance [17]. Diet composition can modify gene physiology and expression, causing alteration of feed conversion ratio. Our study showed that high metabolizable energy (ME) and low crude protein $(\mathrm{CP})$ significantly improved the live weight gain of broiler and feed conversion rate with reduction in feed intake. This indicated that birds can adjust the feed intake with changing energy level. These results were comparable with the results of others [3]. The dietary levels of energy and protein influenced the total feed intake. It was lowered for birds fed diets with HELP and higher in LENP, NELP and LEHP. Leeson et al. [24] stated that the feed intake of commercial broilers strain adequately increased as the dietary energy decreased. As well, diets of low CP and supplemented with amino acids improved the growth rate and feed efficiency [25]. Feeding broiler on $20 \%$ dietary CP and supplemented with amino acids, significantly increased feed intake than $23 \% \mathrm{CP}$ with un-supplemented amino acids [26]. 


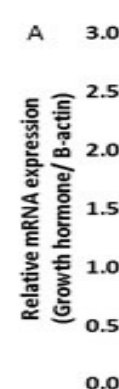

0.00 a

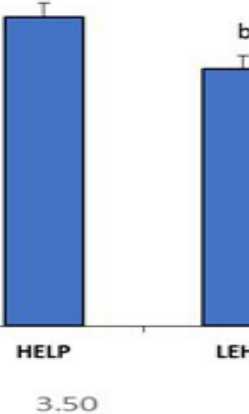

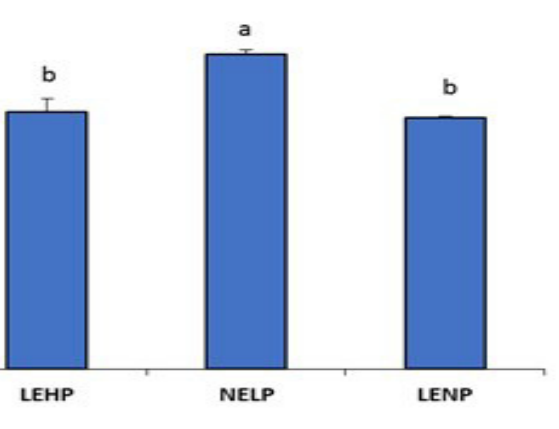

B $\quad 2.50$

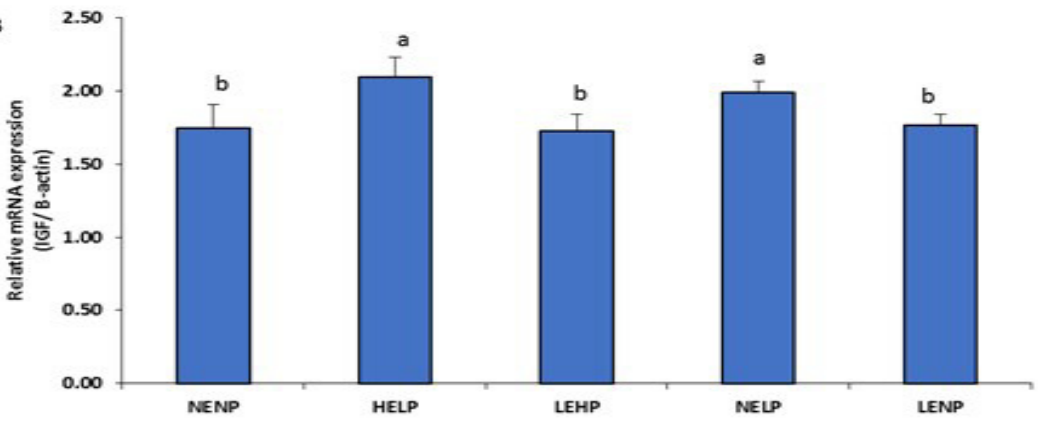

Mygenin = Myostatin
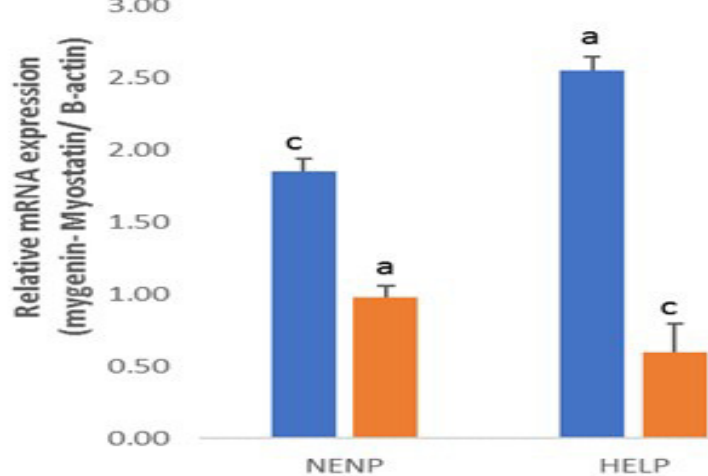

HELP

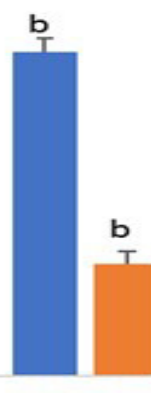

LEHP

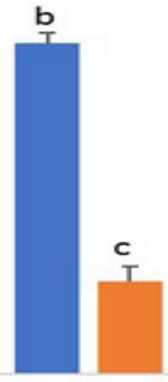

NELP

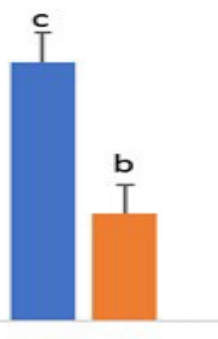

LENP

Figure 1: Effect of varying dietary calorie and protein content on the relative mRNA expression of A) GH, B) IGF-1, C) mygenin and myostatin genes of broilers chicken. ${ }^{1} \mathrm{NENP}=$ normal energy normal protein diet, ${ }^{2} \mathrm{HELP}=$ high energy and low protein diet, ${ }^{3} \mathrm{LEHP}=$ low energy and high protein diet, ${ }^{4} \mathrm{NELP}=$ normal energy and low protein diet, ${ }^{5}$ LENP $=$ low energy and normal protein diet. 
Similarly, Jiang et al. [27] described that broiler feed intake declined as essential amino acid concentration is increased since the bird's requirements were met much earlier. It was observed that inclusion of low protein diet with maintaining optimal levels of essential amino acids, improved broiler performance and feed efficiency. These results agreed with $[25,28]$. Also, the calorie: protein ratio plays an important role as normal ratio of 132-155:1 could be lowered to 155 and 195 of the recommended levels when broilers are fed dietary low protein [29]. Thus, using of HELP and NELP combinations tended to meet the recommended values when compared with the control (NENP) as these groups exhibited lower calorie: protein values (162.27 and $155.65)$ and (180.56 and 175.74) in starter and grower-finisher period, respectively.

From the economic point, excess protein content in broiler diet is of no value where the energy is low. This may be attributed to the wastage of $\mathrm{CP}$ as heat increment after consumption usually in the order of protein $>$ carbohydrate $>$ fat [30]. Additionally, reduction in dietary $\mathrm{CP}$ content significantly increased PER [31]. Broiler protein utilization was improved with higher dietary energy levels and lower levels of dietary CP [32]. Dry matter, $\mathrm{CP}$, starch and fat digestibility were highest in the HELP and NELP groups, while it was lowest in LEHP and LENP. Adequate nutrient utilization by birds greatly depends on the dietary energy content and availability [28]. Zhou et al. [33] showed that the apparent digestibility of DM and CP retention decreased linearly with reducing ME levels in broiler diets from 12.55 to $11.55 \mathrm{MJ} / \mathrm{kg}$. In contrast, Ghazalah and Alsaady [34] observed no significant effects of dietary energy level on organic matter or $\mathrm{CP}$ digestibility of broiler chicks.

The level of body fat and abdominal fat in the HELP diet was non-significant when compared with the other groups. This may be explained by reduction of the feed intake and high feed conversion ratio rate that related to physiological resistance systems of broiler chickens like down-regulation of lipoprotein lipase and become more resistant against high fat intake [35]. Current results in accordance with NRC [19] recommended that, by keeping the ratio between $\mathrm{CP}$ and energy narrow, $\mathrm{CP}$ and energy levels can be lowered down up to a certain limit as long as the balance among amino acids (AAs) is maintained. Several authors described that there are many factors impacting bird's requirements, the most important is the dietary energy and $\mathrm{CP}$ ratio and AAs fortification. Our results indicated that high energy diet accompanied by decrease in eating and drinking frequencies when compared with lower energy diet and these results were directly correlated to the amount of feed intake during the rearing period. Richards [36] reported similar findings. These results support the interaction between frequencies of feed intake and energy density of diet as the bird changes its feeding behaviour as a response to dietary energy content.

The main reason for the increase in productivity is thought to relate to bird behaviour, more precisely, decreased energy use due to less feeding time and more resting time [37]. Frequency of walking behavior was significantly higher in HELP group than other groups. Similary, the interaction between feeding behavior and energy density of food explained that reduced performance in low energy diets because energy maximize the protein utilization for growth [38]. Frequency of wing shaking, leg stretch, flying and preening behaviour was significantly higher in HELP groups. The energy intake is considered a fundamental factor in broiler production and activity [24].

Anther remarkable observation in this study was the higher mRNA expression of growth hormone, IGF-1, myognin in muscle was in HELP and NELP groups. In addition, the expression of myognin was markedly increased in LEHP group. Growth hormone $(\mathrm{GH})$ is necessary for differentiation of muscle, adipocytes, and other cells modulate development and growth [39], synthesis and release of IGF-I through GHR pathway [40]. $\mathrm{GH}$ secretion is regulated by somatotropic action..From our data, it is appearing that dietary proteins and energy content can affect growth hormone, IGF-1, myogenin and myostatin expression levels. The IGF-1 levels have a direct positive correlation with absolute weight gain and carcass cuts in broilers [41]. 
Dietary proteins and energy content influence the IGF-1 mRNA abundance in rat liver [42]. The nitrogen source and amino acid trigger GH-IGF-1 system activation via neurotransmitters and circulating $\mathrm{GH}$ in the liver induces IGF-1 expression [43]. Supplementation approach with free AAs to low-protein diet was reported to be effective in augmenting synthesis of tissue protein via the mechanistic target of rapamycin pathway [44]. Thus, dietary protein content or free AAs, is very important as a modulator for synthesis and deposition of storage proteins needed for muscle growth [45]. Han et al. [46] reported that IGF-1 can promote propagation and protein synthesis in myogenic satellite cells by in vitro Akt/mTOR signaling pathway stimulation. Broiler groups fed CP 22\% and $3100 \mathrm{kcal} / \mathrm{kg}$ of $\mathrm{ME}$ or $20 \% \mathrm{CP}$ and 3300 $\mathrm{kcal} / \mathrm{kg}$ of ME or $21 \% \mathrm{CP}$ and $2800 \mathrm{kcal} / \mathrm{kg}$ ME groups showed higher the IGF-1 expression level [47]. Feeding of pigs on moderate protein diet induced higher mRNA expression of Myogenin and MyoD1 in biceps femoris muscle [44]. Thus, lowering crude protein content with supplemental AAs in the diet did not reduce bird performance and those related to higher availability of dietary essential AAs than in intact protein.

\section{Economic efficiency}

Our results described that using of HELP and NELP diet had a clear impact on productivity and economic efficiency of broiler when compared with other groups. It cleared from these results that the economic efficiency greatly influenced by feed cost and feed conversion rate. Similarly, Reduction of dietary protein level and use of synthetic amino acid is suggested to reduce the feed cost and the environmental pollution of nitrogen [10].

\section{Conclusion}

From the present study, it could be concluded that supplementation of low protein diet with supplemental amino acids and adequate balance of calorie: protein ratio as in HELP (19 \% CP and 3200 ME) and NELP (19\% CP and $3100 \mathrm{ME}$ ) broiler chicken's groups, exhibited a good economic performance and enhanced expression of growth and muscle growth related genes.

\section{Conflict of interest}

The authors declare no conflict of interest.

\section{References}

[1] Sterling, K.G.; Vedenov, D.V.; Pesti, G.M. and Bakalli, R.I. (2005): Economically optimal dietary crude protein and lysine levels for starting broiler chicks. Poult Sci, 84 (1): 29-36.

[2] Brickett, K.E.; Dahiya, J.P.; Classen, H.L. and Gomis, S. (2007): Influence of dietary nutrient density, feed form, and lighting on growth and meat yield of broiler chickens. Poult Sci, 86 (10): 2172-2181.

[3] Kamran, Z.; Mirza, M.A. and Mahmood, S. (2004): Effect of decreasing dietary protein levels with optimum amino acids profile on the performance of broilers. Pak Vet J, 24: 165-168.

[4] Niu, Z.; Shi, J.; Liu, F.; Wang, X.; Gao, C. and Yao, L. (2009): Effects of dietary energy and protein on growth performance and carcass quality of broilers during starter phase. Int J Poult Sci, 8 (5): 508511.

[5] Holsheimer, J.P. and Janssen, W.M. (1991): Limiting amino acids in low protein maize $\square$ soyabean meal diets fed to broiler chicks from 3 to 7 weeks of age. $\mathrm{Br}$ Poult Sci, 32 (1): 151-158.

[6] Zaman, Q.U.; Mushtaq, T.; Nawaz, H.; Mirza, M.A.; Mahmood, S.; Ahmad, T.; et al., (2008): Effect of varying dietary energy and protein on broiler performance in hot climate. Anim Feed Sci Technol, 146 (3): 302-312.

[7] Saleh, E.A.; Watkins, S.E.; Waldroup, A.L. and Waldroup, P.W. (2004): Comparison of energy feeding programs and early feed restriction on live performance and carcass quality of large male broilers grown for further processing at 9 to 12 weeks of age. Int J Poult Scie, 3(1): 61-69.

[8] Behera, N.K.; Babu, L.K.; Sahoo, S.K.; Giri, S.C.; Pati, P.K.; Panigrahi, B. and Joshi, S.K. (2016): Effect of Feeding Different Levels of Protein on Mortality, Carcass Characteristics, Biochemical Parameter, Time Motion Study and 
Economics of Desi Ducks under Intensive System of Rearing. Asian J Anim Sci, 10 (1):106-112.

[9] Jensen, L.S. and Colnago, L. (1991): Amino acids and proteins for broilers and laying hens. Proc. Maryland Nutr. Conf. for Feed Manufacturers, Baltimore, USA: 29-36.

[10] Corzo, A.; Loar, R.E. and Kidd, M.T., (2009): Limitations of dietary isoleucine and valine in broiler chick diets. Poult Sci, 88(9): 1934-1938.

[11] Kumar, C.B.; Gloridoss, R.G.; Singh, K.C. and Prabhu, T.M.; et al., (2015): Impact of second line limiting amino acids' deficiency in broilers fed low protein diets with rapeseed meal and deoiled rice bran. Vet world, 8(3): 350-357.

[12] Wen, C.; Chen, X.; Chen, G.Y.; Wu, P.; Chen, Y.P.; Zhou, Y.M. and Wang, T. (2014): Methionine improves breast muscle growth and alters myogenic gene expression in broilers. J Anim Sci, 92 (3): 1068-1073.

[13] Benjamini, Y. and Hochberg, Y. (1995): Controlling the false discovery rate: a practical and powerful approach to multiple testing. J R Stat Soc. Series B Stat Methodol), 57 (1) : 289-300.

[14] Damayanti, D. (2015): Industry update: Consumption growth trend on poultry feed. Trend Pertumbuhan Konsumsi Pakan Ternak, Mandiri Bank, Indonesia: $1-4$.

[15] Kita K.; Nagao K.; Taneda N.; Inagaki Y.; Hirano K.; Shibata T.; et al., (2002): Insulin-like growth factor binding protein-2 gene expression can be regulated by diet manipulation in several tissues of young chickens. J Nutr, 132(2): $145-151$.

[16] Armstrong, J.D. and Britt, J.H. (1987): Nutritionally induced anestrus in gilt: metabolic and endocrine changes associated with cessation and resumption of estrous cycles. J Anim Sci, 65(2):508523.

[17] National Research Council (NRC). (1994): Nutrition Requirements of poultry. 9th Ed., Washington, DC National Academy Press.

[18] AOAC. (2002): Official Methods of Amlysis. 17th Edn. Association of Official Analytical Chemists, Arlington, VA.

[19] Friesen, O. D.; Guenter, W.; Marquardt, R. R. and Rotter, B. A. (1992): The effect of enzyme on the apparent ME and nutrient digestibility of wheat, barley, oats and rye for the young broiler chick. Poult Sci, 71(10): 1710-1721.

[20] Maquardt, R. R. (1983): A simple spectrophotometer method for the direct determination of uric acid in avian excreta. Poult Sci, 62(10): 2106- 2108.

[21] Fraser, A.F.and Broom, D.M. (1990): Farm animal behaviour and welfare. BaillièreTindall Publ., London, UK.

[22] El-Kerdawy, D.M.A. (1997): Olive pulp as a new energy source for growing rabbits. Egypt J Rabbit Sci, 7: 1-12.

[23] Rosa, P.S.; Faria Filho, D.E.; Dahlke, F.; Vieira, B.S.; Macari, M. and Furlan, R.L. (2007): Effect of energy intake on performance and carcass composition of broiler chickens from two different genetic groups. Rev Bras Cienc Avic, 9 (2): 117-122.

[24] Leeson, S.; Caston, L. and Summers, J.D. (1996): Broiler response to energy or energy and protein dilution in the finisher diet. Poult Sci, 75 (4): 522-528.

[25] Si, J.; Fritts, C.A.; Burnham, D.J. and Waldroup, P.W. (2004): Extent to which crude protein may be reduced in cornsoybean meal broiler diets through amino acid supplementation. Int $\mathrm{J}$ Poult Sci, 3(1): 46-50.

[26] Kidd M.T., Peebles, E.D., Whitmarsh, S.D.; Yeatman, J.B. and Wideman, R.F. Jr. (2001): Growth immunity of broilers chicks as affected by dietary Arginine. Poult Sci, 80(11): 1535-1542.

[27] Jiang, Q.; Waldroup, P.W. and Fritts, C.A. (2005): Improving the utilization of diets low in crude protein for broiler chicken.1 Evaluation of special amino 
acids supplementation to diets low in crude protein. Int J Poult Sci, 4:115-122.

[28] Dairo, F.A.S.; Adesehinwa, A.O.K.; Oluwasola, T.A. and Oluyemi, J.A. (2010): High and low dietary energy and protein levels for broiler chickens. Afr J Agric Res, 5 (15): 2030-2038.

[29] Aftab, U.; Ashraf, M. and Jiang, Z. (2006): Low protein diets for broilers. Worlds Poult Sci J, 62(04): 688-701.

[30] Gous, R.M. and Morris, T.R. (2005): Nutritional interventions in alleviating the effects of high temperatures in broiler production. Worlds Poult Sci J, 61(03): 463-475.

[31] Aletor, V.A.; Hamid, I.I.; Niess, E. and Pfeffer, E. (2000): Low $\square$ protein amino acid $\square$ supplemented diets in broiler chickens: effects on performance, carcass characteristics, whole $\square$ body composition and efficiencies of nutrient utilization. $\mathbf{J}$ Sci Food Agric, 80 (5): 547-554.

[32] Reginatto, M.F.; Ribeiro A.M.; Penz, A.M.; Kessler, A. M. and Krabbe, E. L. (2000): Effect of energy, energy: protein ratio and growing phase on the performance and carcass composition of broilers. Rev Bras Cienc Avic., 2(3): 229-237.

[33] Zhou, Y.; Jiang, Z.; Lv, D. and Wang, T. (2009): Improved energy-utilizing efficiency by enzyme preparation supplement in broiler diets with different metabolizable energy levels. Poult Sci, 88 (2):316-322.

[34] Ghazalah, A.A. and Alsaady, M.A. (2008): Effect of dietary metabolizable energy and microbial phytase levels on broiler performance, nutrients digestibility and minerals utilization. Egypt Poult Sci., 28 (3): 815-832.

[35] Vahdatpour, T.; Nazer-Adl,K.; EbrahimNezhad, Y.; Maheri-Sis, N. and Vahdatpour, S. (2008): The effects of energy increasing and protein lowering by addition of fats to diet on broiler chickens: performance and serum lipids. Asian J Anim Vet Adv, 3(5): 286-292
[36] Richards, M.P. (2003): Genetic regulation of feed intake and energy balance in poultry. Poult Sci, 82(6):907916.

[37] McKinney, L.J. and Teeter, R.G. (2004): Predicting effective caloric value of nonnutritive factors: I. Pellet quality and II. Prediction of consequential formulation dead zones. Poult Sci, 83(7):1165-1174.

[38] Classen, H.L. (2013): Response of broiler chickens to dietary energy and its relationship to amino acid nutrition. In 24th Annual Australian Poultry Science Symposium, Sydney, New South Wales, Australia, 17-20 February 2013 (pp. 107114). Poultry Research Foundation.

[39] Kim, J.W. (2010): The endocrine regulation of chicken growth. AsianAustralas J Anim Sci, 23 (12):1668-1676.

[40] Del Vesco, A.P.; Gasparino, E.; Oliveira Neto, A.R.; Guimarães, S.E.; Marcato, S.M. and Voltolini, D.M. (2013): Dietary methionine effects on IGF-I and GHR mRNA expression in broilers. Genet Mol Res, 12(4):6414-6423.

[41] Kini, A.; Fernandes, C. and Suryawanshi, D. (2016): Effect of KiFAY on Performance, Insulin-like Growth Factor1, and Thyroid Hormones in Broilers. Asian-Australas J Anim Sci, 29 (10): 1451.

[42] Emler, C.A. and Schalch. D.S. (1987): Nutritionally-induced changes in hepatic Insulin-like Growth Factor I (IGF-I) gene expression in rats. Endocrinol, 120(2): 832-883.

[43] Garcia-Tornadu, I.; Risso, G.; PerezMillan, M.I.; Noain, D.and Diaz-Torga, G.; Low, M.J. et al., (2010): Neurotransmitter modulation of the GHRH-GH axis. Front Horm Res, 38: 59-69

[44] Deng, D.; Yao, K.; Chu, W.; Li, T.; Huang, R.; Yin, Y.; et al., (2009): Impaired translation initiation activation and reduced protein synthesis in weaned piglets fed a low-protein diet. J Nutr Biochem, 20 (7):544-552. 
[45] Liu, Y.; Li, F.; Kong, X.; Tan, B.; Li, Y.; Duan, Y.; et al., (2015): Signaling pathways related to protein synthesis and amino acid concentration in pig skeletal muscles depend on the dietary protein level, genotype and developmental stages. Plos One, 10 (9): 0138277.

[46] Han, B.; Tong, J.; Zhu, M.J.; Ma, C. and $\mathrm{Du}, \quad \mathrm{M}$. (2008): Insulin $\square$ like growth factor $\square 1$ (IGF $\square 1$ ) and leucine activate pig myogenic satellite cells through mammalian target of rapamycin (mTOR) pathway. Mol Reprod Dev, 75 (5):810817.

[47] Saragih, H.T. and Daryono, B.S. (2016): The Effect of Varying Level of Crude Protein and Energy on Insulin like Growth Factor-I Gene Expression in Indonesian Hybrid Chicken. Int J Poult Sci, 16 (1): 1-5.

\footnotetext{
الملخص العربي

تأثثير كمية الطاقة و البروتين في العليقة علي الاداء والستوك و التنظيم الجيني المسؤل عن النمو والجدوي

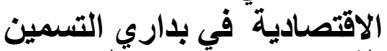

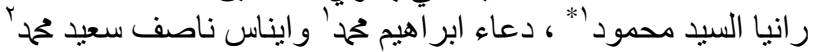

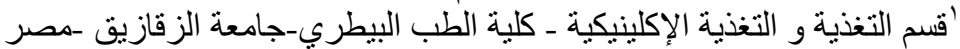

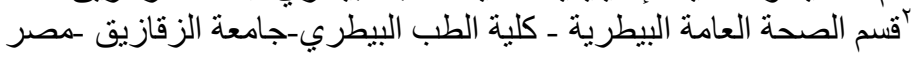

الهدف من هذه الدر اسـة هو در اسـة تأثير الكميـات المختلفة من الطاقة والبروتين في العليقة علي الاداء و السـلوك و التنظيم

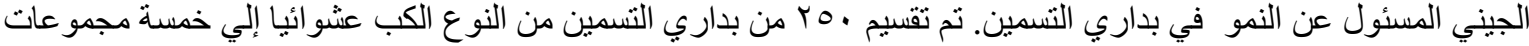

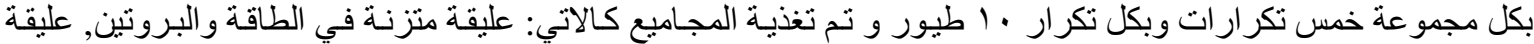

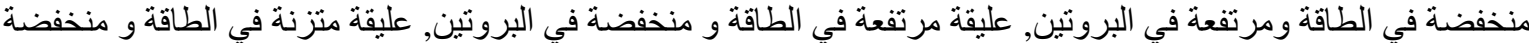

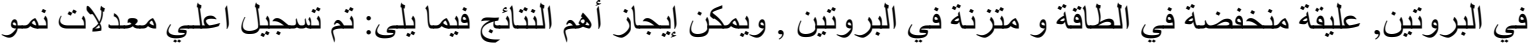

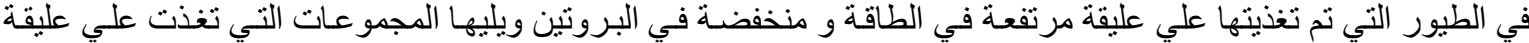

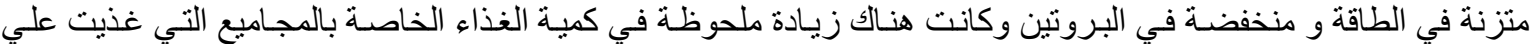

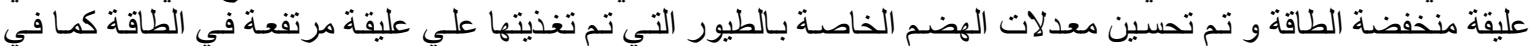

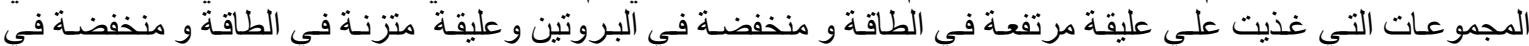

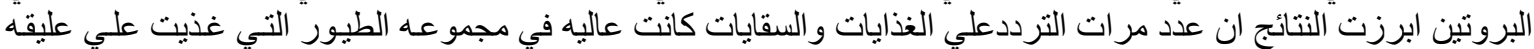

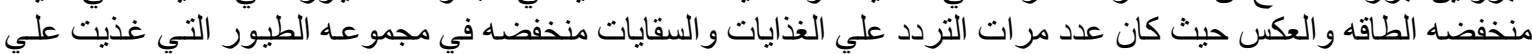

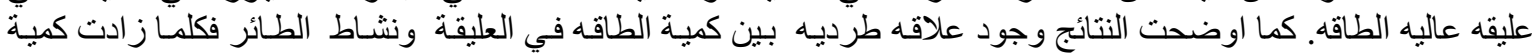

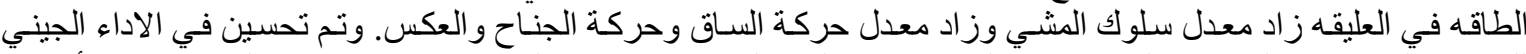

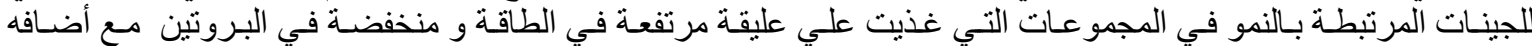

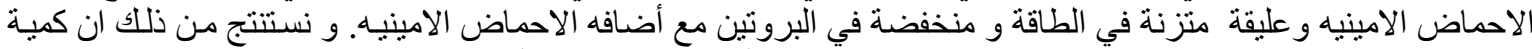

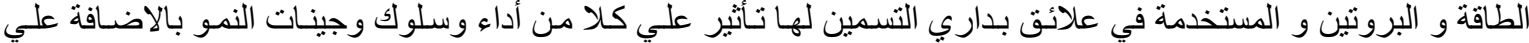

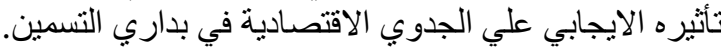

